\title{
Impact of Climate Variability and Incidence on Dengue Hemorrhagic Fever in Palembang City, South Sumatra, Indonesia
}

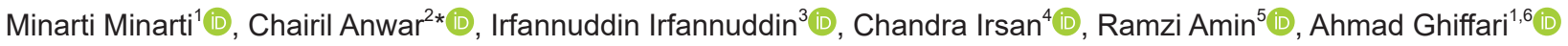 \\ ${ }^{1}$ Department of Environmental Science, Graduate School, Universitas Sriwijaya, Palembang, Indonesia; ${ }^{2}$ Department of \\ Parasitology, Faculty of Medicine, Universitas Sriwijaya, Ogan Ilir, South Sumatra, Indonesia; ${ }^{3}$ Department of Physiology, Faculty \\ of Medicine, Universitas Sriwijaya, Indralaya, South Sumatra, Indonesia; ${ }^{4}$ Department of Plant Protection, Faculty of Agriculture, \\ Universitas Sriwijaya, Ogan Ilir, South Sumatra, Indonesia; ${ }^{5}$ Department of Ophthalmology, Faculty of Medicine, Universitas \\ Sriwijaya, Palembang, Indonesia; ${ }^{6}$ Department of Parasitology, Faculty of Medicine, University of Muhammadiyah Palembang, \\ Palembang, Indonesia
}

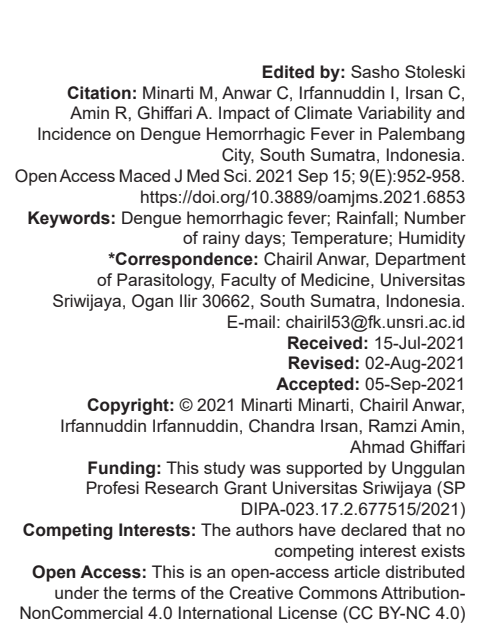

\begin{abstract}
BACKGROUND: Dengue hemorrhagic fever (DHF) is a dengue virus infection transmitted by Aedes spp. Climate has a profound influence on mosquito breeding. Palembang has the highest rate of DHF in South Sumatra.

AIM: This study aimed to investigate the relationship between the components of climate factors and the incidence of DHF in Palembang.

METHODS: This study was cross sectional, with an observational analytic approach. The Palembang City Health Office compiled data on DHF incidence rates from 2016 to 2020. Climatic factor data (rainfall, number of rainy days temperature, humidity, wind speed, and sun irradiance) were collected from the Climatology Station Class I Palembang - BMKG Station and Task Force that same year. The Spearman test was used to conduct the correlation test.

RESULTS: Between 2016 and 2020, there were 3398 DHF patients. From January to May, DHF increased. There was a significant correlation between rainfall $(r=0.320 ; p=0.005)$, number of rainy days $(r=0.295 ; p=0.020)$ temperature $(r=0.371 ; p=0.040)$, and humidity $(r=0.221 ; p=0.024)$, wind speed $(r=0.76 ; p=0.492)$, and sunlight $(r=0.008 ; p=0.865)$

CONCLUSION: Rainfall, the number of rainy days, and temperature were three climatic factors determining the increase in dengue incidence. Vector control approach must start around October, 2 months before the high DHF cases in Palembang.
\end{abstract}

\section{Introduction}

Dengue fever affects about 400 million individuals globally each year [1]. There are four serotypes of dengue, which are transmitted by Aedes mosquitoes [2]; Aedes aegypti is more prevalent indoors, as a container breeder, while Aedes albopictus is more common outside, at city's outskirts. There is a tetravalent dengue vaccine; however, it is not widely utilized [3]. Concerns regarding the safety of the dengue vaccine have hampered its use. Children who had never been exposed to dengue before getting the vaccine had $50 \%$ increased risk of hospitalization [4]. The most effective method to reduce dengue transmission is to control vectors [5].

Transmission occurs across various biological zones and environmental circumstances [6], [7], [8]. The connection between vector density and disease transmission is complex and unpredictable [6], [7]. Incomplete coverage and improper application, pesticide resistance, high labor costs, and community apathy make comprehensive vector control challenging to establish and maintain [9]. Some research shows that vector management methods have little impact on entomological indicators [5], [10], [11]. Most vector control technique assessments utilize entomological data rather than disease incidence rates. The human disease was unaffected by substantial decreases in vector indices [12], [13], [14], [15], [16]. The optimal timing of insecticide fogging and its impact on reducing dengue cases were greatly influenced by seasonality and the level of transmission intensity [16].

The Ministry of Health $(\mathrm{MoH})$ used a threepronged coordinated vector approach since the 1980s. An eradication campaign led by 3 million families got underway. Through television, radio, and the internet, the general population was regularly taught how to detect Aedes larvae and administer larvicide. Second, Abate $®$ was employed to destroy larvae by both residents and $\mathrm{MoH}$ personnel. Abate was made accessible at local clinics for use with larvae in 
water containers; for these methods to be effective, community involvement is required. Finally, in impacted regions, the $\mathrm{MoH}$ employed reactive outdoor pesticide fogging. The plan was to spray $100 \mathrm{~m}$ around the home of a dengue sufferer who had been hospitalized for a week. However, the trend of outbreaks in Palembang in 1998 showed the increase in dengue cases reached three doubled between January and April [17]. These vector control did not result in a significant reduction in dengue incidence. We hypothesized that climatic factors should be considered when planning a control strategy against dengue vectors. There is a need to understand better and predict dengue outbreaks and transmission risk based on the temporal data so that vector control resources can be allocated optimally.

\section{Materials and Methods}

A cross-sectional study was used in this research. The Palembang Health Office provided data on the incidence of dengue hemorrhagic fever (DHF), and Climatology Class I Palembang - Station and UPT BMKG provided climate data (rainfall, number of rainy days, temperature, humidity, wind speed, and duration of sunshine). Due to the coronavirus disease (COVID-19) pandemic, it was obligated to follow health protocols such as wearing masks, washing hands, and keeping a safe distance during data collection. SPSS was used to gather, process, and calculate all data. The Kolmogorov-Smirnov and Spearman correlation tests were used in a bivariate analysis, with $p=0.05$ considered statistically significant.

\section{Results and Discussion}

\section{The incidence rate of DHF based on temporal analysis and subdistrict categories}

Data of DHF incidence immensely varied every year and also in months. The number of DHF patients in 2020 decreased compared to the previous year (Figure 1). DHF incidence rose from January to May, then fell sharply from June to September. In this regard, it is noteworthy that the pattern of DHF patients has remained relatively consistent over the past 5 years. A general description of DHF incidence and climate over 5 years (2016-2020) is depicted in Figure 2. Seasonality and the degree of transmission intensity significantly affected the optimum timing of pesticide fogging and its impact on decreasing dengue incidence. The best time to fog insecticides to decrease dengue incidence is between the start of the rainy season and the peak of a large epidemic, rather than waiting

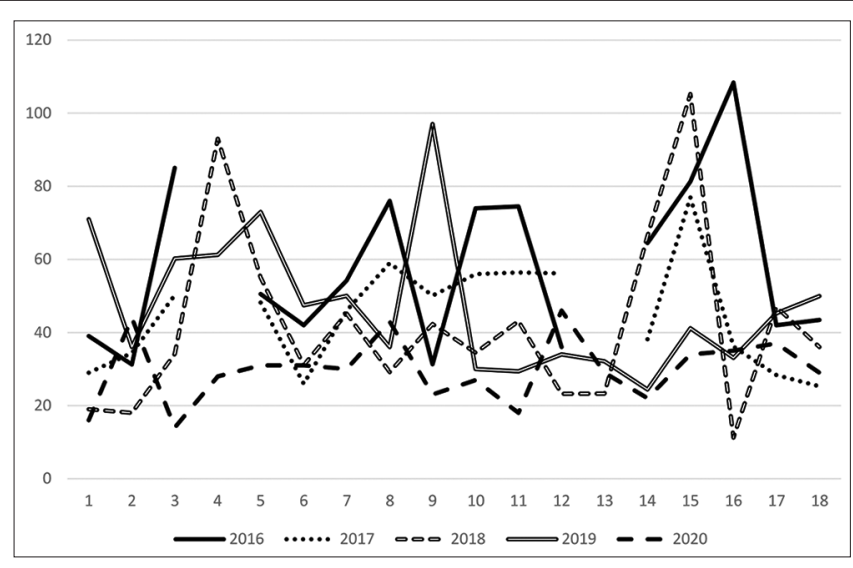

Figure 1: The incidence rate of dengue hemorrhagic fever by subdistrict in Palembang city

until the peak of a significant outbreak happens [16]. Dengue incidence was shown to be associated with several meteorological factors in Binh Thuan Province, Vietnam. A look at dengue population transmission patterns from 1996 to 2001 found a robust annual oscillation mode with a substantial multi-annual cycle. When it comes to developing early warning systems, the presence of these plausible climatic factors may be especially relevant since accurate predictors of dengue epidemics may help reduce the risk of dengue outbreaks [18]. Predictions of dengue season based on climate variability have led to early warning systems. Preemptive countermeasures innovative control approach for $A$. aegypti to reduce populations during periods of rapid population increase resulted in the first 2 months of the rainy season being sufficient to reduce $A$. aegypti numbers associated with the onset of dengue transmission [13]. There is no clear evidence for recommending peridomestic space spraying as a single, effective control intervention. Thus, peridomestic space spraying is more likely best applied as part of an integrated vector management strategy. The effectiveness of this intervention should be measured in terms of impact on both adult and immature mosquito populations and disease transmission [14]

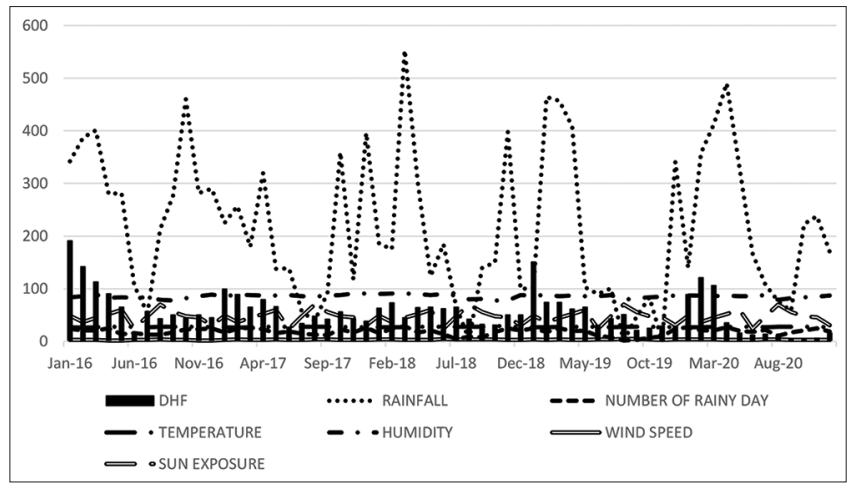

Figure 2: Monthly distribution of dengue virus infection patients based on climatic factors

Figure 1 illustrates that all 18 Palembang subdistricts reported a decline in dengue cases by 2020; however, from 2016 to 2019, three subdistricts, 
Sukarami, Seberang Ulu 1, and Ilir Barat 1, had a high incidence trend. Whereas the Sematang Borang, Gandus, and Kalidoni subdistricts are classified as sporadic yet located on the city's outskirts, others are classified as endemic and are located in the city center [19], [20]. A. aegypti mosquito is mainly found in houses in the city center. In contrast, $A$. albopictus is found outdoors in the city's outskirts [21]. Despite good public knowledge, the behavior of preventing and controlling mosquito nests must be improved to break the chain of transmission through the elimination of breeding of $A$. aegypti mosquito's site [22]. The community effectiveness of temephos depended on factors such as quality of delivery, water turnover rate, type of water, and environmental factors such as organic debris, temperature, and exposure to sunlight. As a single intervention, temephos effectively suppressed entomological indices; however, the same effect has not been observed when temephos was applied in combination with other interventions. There is no evidence to suggest that temephos use is associated with reductions in dengue transmission [15].

\section{The incidence rate of DHF based on climatic factors}

Over 5 years, 3398 cases of DHF have been reported. Every year, the distribution of dengue cases follows a cyclical pattern. The Spearman correlation test reveals that rainfall, the number of rainy days, and temperature all impact the occurrence of DHF rainfall $(r=0.320 ; p=0.005)$. The relative number of rainy days correlated with DHF $(r=0.295 ; p=0.020)$. The incidence of DHF was also affected by temperature $(r=0.371$; $p=0.040$ ), whereas humidity, wind speed, and sunlight do not affect the incidence of DHF (Figure 3). Data on the weather in Palembang from 2016 to 2020. In Palembang, monthly rainfall peaked in January and then declined rapidly until April. The lowest monthly rainfall $(2.0 \mathrm{~mm})$ was in 2019 . In 2018, March had the rainiest days (29/month), while August had the least (2/ month). Temperature fluctuations every month as the daily average temperature in 5 years did not show a significant increase and tended to fluctuate relatively low, as the highest temperature in 2020 was $33.9^{\circ} \mathrm{C}$ and a minimum of $24.2^{\circ} \mathrm{C}$. Every month, the humidity level rises. In 2018, the highest average air humidity was $91.4 \%$, and the lowest was $77.6 \%$. Weather in Palembang ranged from 4.2 to 2.5 knots from 2016 to 2020. The sun's irradiance was $50.2 \%$.

Rainfall in Palembang ranged from 0.0 to $45.84 \mathrm{~mm}$ from 2016 to 2020 . These conditions are ideal for the development and survival of Aedes mosquito. More puddles in the house or yard from around the house can result from light rain. Rainfall serves to enhance the availability of $A$. aegypti vector habitat. The Aedes mosquito's eggs can survive and keep conditions secure. When the rainy season arrives, and the eggs of this type of mosquito are exposed to just a little water, they hatch promptly. DHF transmission is sensitive to fluctuations in rainfall [23]. Vector abundance and population will be affected by climate change, such as rainfall, thus affecting the transmission of DHF [24]. In India, rainfall is the single factor in the increase in the incidence of DHF [25]. Rainfall in the Philippines is associated with an increased incidence of DHF [26]. The study results were inversely proportional in Sri Lanka, which showed no relationship between rainfall and an increase in DHF [27]. Nonetheless, excess rain can also throw away mosquito eggs, larvae, pupae, and mosquito breeding grounds [28]. In South Taiwan, mosquito density and rainfall have a negative relationship when it rains heavily. In recent years, it has been noticed that many mosquito eggs and larvae are drifting away from breeding sites [29].

The number of rainy days in Palembang was $<3 \mathrm{~mm} /$ day and $<15 \mathrm{~mm} /$ day on 50 and $75 \%$ of days, respectively. The number of consecutive rainy days in the previous 2 months, increasing the probability of at least one case of DHF occurring 2 months later, increased by $17 \%$. The number of rainy days is a robust predictor [30]. The number of days of rainfall plays an essential role in the dengue epidemic [31], [32].

The average humidity in Palembang was $87.7 \%$, and the analysis discovered that it was not associated with the incidence of DHF. Humidity $60-70 \%$ affects mosquitoes' lives; mosquitoes cannot breed when humidity is $<60 \%$. It can interfere with the respiratory system, so mosquitoes' lifespan is short [33]. A study from 1983 through 2001, collecting monthly case numbers, temperature, humidity, and rainfall, characterizes seasonal dengue virus transmission cycles and identified seasonal transmission cycle structural variations. Larger epidemics are affected by temperature and humidity. Dualistic transmission $80 \%$ of 1.2 million severe dengue cases occurred at $27-29^{\circ} \mathrm{C}$ and $75 \%$ humidity [6]. It is better to act early to reduce epidemic size. Examining the relationship between weather, vector dynamics, and viral transmission help enhance human-to-human virus transmission models, dynamic risk assessment, and early epidemic.

The temperature range in Palembang was between $33.6^{\circ} \mathrm{C}$ and $24.6^{\circ} \mathrm{C}$. The temperature was the most significant contributor to the occurrence of DHF in Nepal, accounting for nearly $90 \%$ of the influence [34]. An average temperature of $25-30^{\circ} \mathrm{C}$ provides an ideal environment for mosquito vector breeding and development [35]. Temperature influences the virus's extrinsic incubation period and mosquitoes' biting activity [36]. In the mosquito body, the development of extrinsic incubation is $<9$ and 5 days, at temperatures of $28^{\circ} \mathrm{C}$ and $30^{\circ} \mathrm{C}$, respectively. Female mosquitoes' reproductive cycle is affected by the temperature of their environment, with female mosquito fertilization being reduced at temperatures below $20^{\circ} \mathrm{C}$ [37]. Biting female mosquitoes is influenced by their environment's temperature, which will increase the spread of dengue 


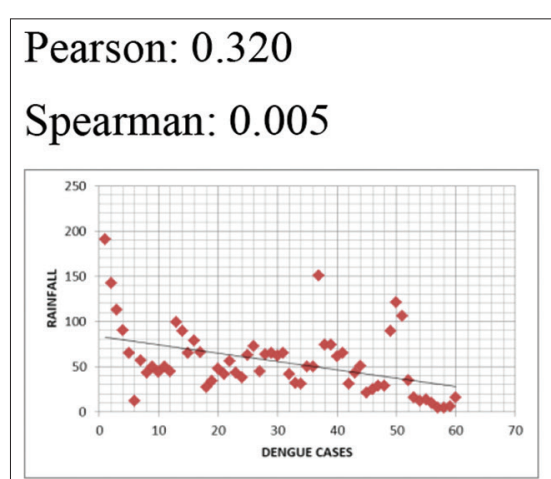

Pearson: 0.211

Spearman: 0.024

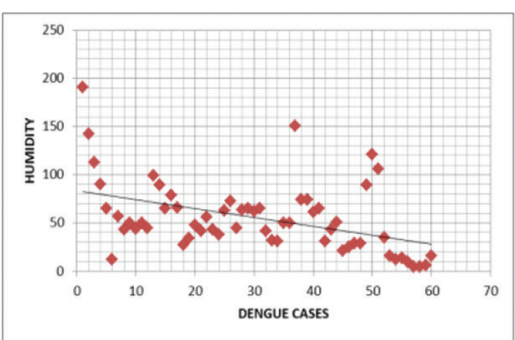

Pearson: 0.295

Spearman: 0.020

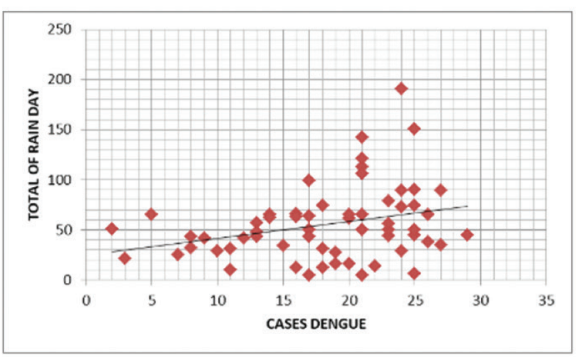

Pearson: 0.76

Spearman: 0.492

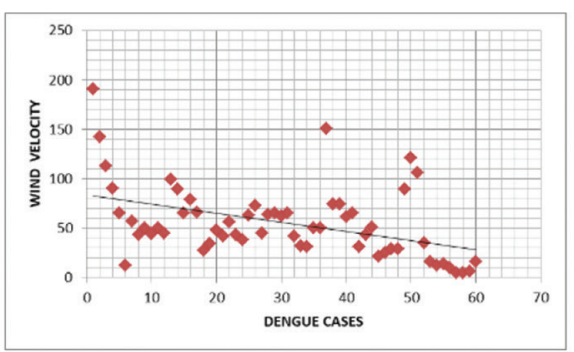

Pearson: 0.371

Spearman: 0.040

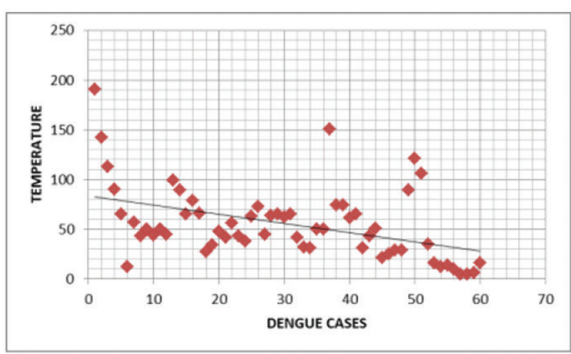

Pearson: 0.008

Spearman: 0.865

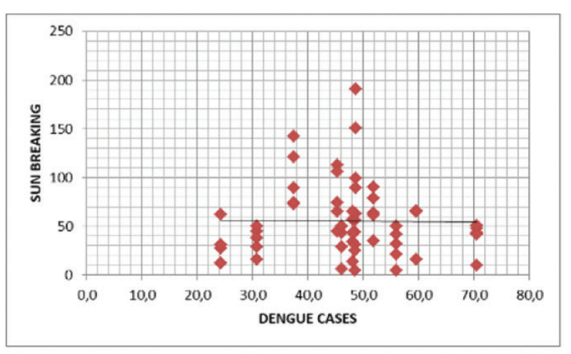

Figure 3: Scatter plots of the relationship between climatic factors and dengue hemorrhagic fever cases in Palembang using Spearman correlation

disease. There is a non-linear relationship between temperature rise and changes in the incidence of dengue cases [38], and temperature plays an essential role in influencing the population dynamics of Aedes mosquitoes [39]. Increase in DHF incidence ratio as the weekly average increase from $1^{\circ} \mathrm{C}$ [38]. A large number of cases of DHF can be attributed to temperature [40], [41], [42]. Climatic factors such as temperature, humidity, and rainfall [43], [44], [45] [46] can prolong the transmission period of DHF [47]. Temperatures of $24-39^{\circ} \mathrm{C}$ play a significant role in mosquitoes' development, survival, and feeding behavior to promote viral replication in vectors [48]; thus, DHF will increase by $35 \%$ per $1^{\circ} \mathrm{C}$ [49].

The increase in wind speed in Palembang has a weak and negative correlation strength and did not affect the incidence of DHF. Although wind speed reduces the flying ability of mosquitoes, the results are similar, where there is no decrease in dengue transmission [50]. Different results where wind speed decreases dengue transmission, obtained from correlation and regression analysis of the relationship in Malaysia [51]. Dengue transmission in Malaysia is reduced by high wind speeds. There was a significant link between DHF incidence and exposure to mosquito flying activities and human interaction in Malaysian urban areas between 2012 and 2016 [51]. Wind speed contributes to exposure due to mosquitoes flying in or out of the house [52]. Wind speed affects or inhibits mosquito flight distance, thereby determining human-mosquito contact [53].
In Palembang, the duration of sun exposure had no significant relationship with dengue cases. The movement of mosquitos in search of food or a place to rest is greatly affected by sunlight. The female mosquito Ae. aegypti hunts for prey during the day when sunlight directly influences it. High levels of sunlight cause the air temperature to rise and the percentage of humidity to fall, interfering with mosquito survival. As a result, one of the factors that can influence mosquito productivity is sun exposure [54].

The DHF case in Palembang was caused by several determinants, besides the climate change factor. The public health issue such as locals' knowledge, attitude, and practice toward DHF control has impacted the disease control [19]. Fully enclosed mosquito breeding sites will increase awareness to create good environmental sanitation [55]. Another factor, such as community activity, has been implemented to prevent DHF incidence. Whereas ecological conditions and community behavior are factors, community behavior has a more significant influence on increasing the risk of DHF incidence [56].

This study has limitations because it uses secondary data. As a result, predicting dengue incidence increases when different weather and other factors are considered. Furthermore, it is essential to concentrate on vector population reduction and the limitation of human-vector contact when developing predictions. It is necessary to do that during climate change anomalies. 


\section{Conclusions}

Palembang has the highest incidence of DHF in 5 years in 2019. In terms of the early warning system, rainfall, the frequency of rainy episodes, and temperature were the three main climatic factors that influenced dengue incidence. Peridomestic spraying and temephos application were most effective beginning in October, 2 months before the incidence of DHF increased.

\section{Acknowledgment}

We would like to thank the Health Department of Palembang municipality; also, the Climatology Class I Palembang - Station, and UPT BMKG for cooperating in this study. The study was founded by Unggulan Profesi Research Grant Universitas Sriwijaya (SP DIPA-023.17.2.677515/2021), with the Rector's Decree Number of 0014/UN9/SK.LP2M.PT/2021.

\section{References}

1. Bhatt S, Gething PW, Brady OJ, Messina JP, Farlow AW, Moyes CL, et al. The global distribution and burden of dengue. Nature. 2013;496(7446):504-7. http://doi.org/10.1038/ nature12060.the

PMid:23563266

2. Bowman LR, Runge-Ranzinger $\mathrm{S}$, McCall PJ. Assessing the relationship between vector indices and dengue transmission: A systematic review of the evidence. PLoS Negl Trop Dis. 2014;8(5):e2848. http://doi.org/10.1371/journal.pntd.0002848 PMid:24810901

3. Guy B, Lang J, Saville M, Jackson N. Vaccination against dengue: Challenges and current developments. Ann Rev Med. 2016;67:387-404. http://doi.org/10.1146/ annurev-med-091014-090848 PMid:26515983

4. Sridhar S, Luedtke A, Langevin E, Zhu M, Bonaparte $M$, Machabert $\mathrm{T}$, et al. Effect of dengue serostatus on dengue vaccine safety and efficacy. N Engl J Med. 2018;379:327-40. http://doi.org/10.1056/nejmoa1800820

PMid:29897841

5. Bowman LR, Donegan S, Mccall PJ. Is dengue vector control deficient in effectiveness or evidence ?: Systematic review and meta-analysis. PLoS Negl Trop Dis. 2016;10(3):1-24. http://doi. org/10.1371/journal.pntd.0004551

PMid:26986468

6. Campbell KM, Lin CD, lamsirithaworn S, Scott TW. The complex relationship between weather and dengue virus transmission in Thailand. Am J Trop Med Hyg. 2013;89(6):1066-80. http://doi. org/10.4269/ajtmh.13-0321

PMid:23958906

7. Johansson MA, Cummings DA, Glass GE. Multiyear climate variability and dengue EI Niño Southern oscillation, weather, and dengue incidence in Puerto Rico, Mexico, and Thailand: A longitudinal data analysis. PLoS Med. 2009;6(11):11-2. http:// doi.org/10.1371/journal.pmed.1000168

PMid:19918363

8. Stoddard ST, Wearing HJ, Reiner RC Jr., Morrison AC, Astete H, Vilcarromero $\mathrm{S}$, et al. Long-term and seasonal dynamics of dengue in Iquitos, Peru. PLoS Negl Trop Dis. 2014;8(7):e3003. http://doi.org/10.1371/journal.pntd.0003003

PMid:25033412

9. Hamid PH, Prastowo J, Widyasari A, Taubert A, Hermosilla C. Knockdown resistance (kdr) of the voltage-gated sodium channel gene of Aedes aegypti population in Denpasar, Bali, Indonesia. Parasit Vectors. 2017;10(1):1-9. http://doi. org/10.1186/s13071-017-2215-4

10. Erlanger $\mathrm{T}$, Keiser J, Utzinger J. Effect of dengue vector control interventions on entomological parameters in developing countries: A systematic review and metaanalysis. Med Vet Entomol. 2008;22(3):203-21. http://doi. org/10.1111/j.1365-2915.2008.00740.x

\section{PMid:18816269}

11. Perich MJ, Davila G, Turner A, Garcia A, Nelson M. Behavior of resting Aedes aegypti (Culicidae: Diptera) and its relation to ultra-low volume adulticide efficacy in Panama City, Panama. J Med Entomol. 2000;37(4):541-6. http://doi. org/10.1603/0022-2585-37.4.541

\section{PMid:10916294}

12. Gurtler RE, Garelli FM, Coto HD. Effects of a five-year citywide intervention program to control Aedes aegypti and prevent Dengue outbreaks in Northern Argentina. PLoS Negl Trop Dis. 2009;3(4):e427. http://doi.org/10.1371/journal.pntd.0000427

13. Chadee DD. Impact of pre-seasonal focal treatment on population densities of the mosquito Aedes aegypti in Trinidad, West Indies: A preliminary study. Acta Trop. 2009;109:236-40. http://doi.org/10.1016/j.actatropica.2008.12.001

PMid: 19114025

14. EsuE,LenhartA,SmithL, HorstickO.Effectivenessofperidomestic space spraying with insecticide on dengue transmission: Systematic review. Trop Med Int Health. 2010;15(5):619-31. http://doi.org/10.1111/j.1365-3156.2010.02489.x PMid:20214764

15. George L, Lenhart A, Toledo J, Lazaro A, Han WW, Velayudhan $\mathrm{R}$, et al. Community-effectiveness of temephos for dengue vector control: A systematic literature review. PLoS Negl Trop Dis. 2015;9(9):e0004006. http://doi.org/10.1371/journal. pntd.0004006

PMid:26371470

16. Oki M, Sunahara T, Hashizume M, Yamamoto T. Optimal timing of Insecticide fogging to minimize dengue cases: Modeling dengue transmission among various seasonalities and transmission intensities. PLoS Negl Trop Dis. 2011;5(10):e1367. http://doi. org/10.1371/journal.pntd.0001367

PMid:22039560

17. Corwin AL, Larasati RP, Bangs MJ, Wuryadi S, Arjoso S, Sukri N et al. Epidemic dengue transmission in Southern Sumatra, Indonesia. Trans R Soc Trop Med Hyg. 2001;95(3):257-65. http://doi.org/10.1016/S0035-9203(01)90229-9 PMid:11490992

18. Thai KT, Cazelles B, Van Nguyen N, Vo LT, Boni MF, Farrar J, et al. Dengue dynamics in binh thuan province, Southern Vietnam: Periodicity, synchronicity and climate variability. PLoS Negl Trop Dis. 2010;4(7):1-8. http://doi.org/10.1371/journal. pntd.0000747 PMid:20644621

19. Priyadi P, Indriyati E, Damanik H. In the area of one Ulu publik 
health center, Seberang Ulu I district Palembang city in 2020. J Dunia Kesmas. 2020;9(4):449-56.

20. Sari DE. Knowledge, attitude and education with prevention of Dengue fever using the principle of draining, closing and reusing. Citra Delima J IIm STIKES Citra Delima Bangka Belitung. 2020;3(2):163-70.

21. Anwar C, Lavita RA, Handayani D. Identification and distribution of Aedes Sp. as a vector of dengue hemorrhagic fever in several districts in South Sumatra. MKS. 2014;46(2):111-7.

22. Wurisastuti T, Sitorus H, Oktavia S. Relationship of community behavior with cases of dengue fever in the city of Palembang South Sumatera. Spirakel. 20179(1):34-40. http://doi. org/10.22435/spirakel.v8i2.7383

23. Benedum CM, Seidahmed OM, Eltahir EA, Markuzon $N$. Statistical modeling of the effect of rainfall flushing on dengue transmission in Singapore. PLoS Negl Trop Dis. 2018;12(12):e0006935. http://doi.org/10.1371/journal. pntd.0006935

PMid:30521523

24. Nosrat C, Altamirano J, Anyamba A, Caldwell JM, Damoah R, Mutuku F, et al. Impact of recent climate extremes on mosquitoborne disease transmission in Kenya. 2021;15(3):e0009182. http://doi.org/10.1371/journal.pntd.0009182 PMid:33735293

25. Nair DG, Aravind NP. Association between rainfall and the prevalence of clinical cases of dengue in Thiruvananthapuram district, India. Int J Mosquito Res. 2020;2020:488. http://doi. org/10.22271/23487941.2020.v7.6a.488

26. Zafra B. Predicting dengue in the Philippines using artificial neural network. medRxiv. 2020;2020:8-13. http://doi. org/10.1101/2020.10.08.20209718

27. Hooshyar M, Wagner CE, Baker RE, Yang W, Vecchi GA, Metcalf CJ, et al. Dengue seasonality and non-monotonic response to moisture: A model-data analysis of Sri lanka incidence from 2011 to 2016. arXiv. 2020;2020:2847.

28. Yuan HY, Liang J, Lin PS, Sucipto K, Tsegaye MM, Wen $\mathrm{TH}$, et al. The effects of seasonal climate variability on dengue annual incidence in Hong Kong: A modelling study. Sci Rep. 2020;10(1):1-11. http://doi.org/10.1038/ s41598-020-60309-7

29. Lai YH. The climatic factors affecting dengue fever outbreaks in Southern Taiwan: An application of symbolic data analysis. Biomed Eng Online. 2018;17(s2):148. http://doi.org/10.1186/ s12938-018-0575-4 PMid:30396346

30. Muurlink OT, Stephenson P, Islam MZ, Taylor-Robinson AW. Long-term predictors of dengue outbreaks in Bangladesh: A data mining approach. Infect Dis Model. 2018;3:322-30. http:// doi.org/10.1016/j.idm.2018.11.004

31. Brady OJ, Johansson MA, Guerra CA, Bhatt S, Golding N, Pigott DM, et al. Modelling adult Aedes aegypti and Aedes albopictus survival at different temperatures in laboratory and field settings. Parasit Vectors. 2013;6:351.

PMid:24330720

32. Karunarathna KA, Sriranganesan J. Impact of climatic factors on dengue incidences in eastern province, Sri Lanka. Int J Trop Dis Health. 2019;40(3):1-19. http://doi.org/10.9734/IJTDH/2019/ v40i330228

33. Shimmei $\mathrm{K}$, Nakamura $\mathrm{T}, \mathrm{Ng} \mathrm{CF}$, Hashizume M, Murakami $\mathrm{Y}$, Maruyama A, et al. Association between seasonal influenza and absolute humidity: Time-series analysis with daily surveillance data in Japan. Sci Rep. 2020;10(1):7764. http://doi.org/10.1038/ s41598-020-63712-2

PMid:32385282

34. Acharya BK, Cao C, Xu M, Khanal L, Naeem S, Pandit S. Present and future of dengue fever in Nepal: Mapping climatic suitability by ecological niche model. Int $\mathrm{J}$ Environ Res Public Health. 2018;15(187):1-15. http://doi.org/10.3390/ijerph15020187 PMid:29360797

35. Morgan J, Strode C, Salcedo-Sora JE. Climatic and socioeconomic factors supporting the co-circulation of dengue, Zika and chikungunya in three different ecosystems in Colombia. PLoS Negl Trop Dis. 2021;15(3):1-29. http://doi.org/10.1371/ journal.pntd.0009259

PMid:33705409

36. Kamiya T, Greischar MA, Wadhawan K, Gilbert B, Paaijmans K, Mideo N. Temperature-dependent variation in the extrinsic incubation period elevates the risk of vector-borne disease emergence. Epidemics. 2020;30:100382. http://doi. org/10.1016/j.epidem.2019.100382

PMid:32004794

37. Drakou K, Nikolaou T, Vasquez M, Petric D, Michaelakis A, Kapranas A, et al. The effect of weather variables on mosquito activity: A snapshot of the main point of entry of Cyprus. Int $\mathrm{J}$ Environ Res Public Health. 2020;17(1403):1-10. http://doi. org/10.3390/ijerph17041403

PMid:32098137

38. Charette M, Berrang-Ford L, Coomes O, Llanos-Cuentas EA, Cárcamo $\mathrm{C}$, Kulkarni $\mathrm{M}$, et al. Dengue incidence and sociodemographic conditions in Pucallpa, Peruvian Amazon: What role for modification of the dengue-temperature relationship? Am J Trop Med Hyg. 2020;102(1):180-90. http:// doi.org/10.4269/ajtmh.19-0033

PMid:31701852

39. Jia P, Liang L, Tan X, Chen J, Chen X. Potential effects of heat waves on the population dynamics of the dengue mosquito Aedes albopictus. PLoS Negl Trop Dis. 2019;13(7):e0007528. http://doi.org/10.1371/journal.pntd.0007528

PMid:31276467

40. Cheng J, Bambrick H, Yakob L, Devine G, Frentiu FD Toan DT, et al. Heatwaves and dengue outbreaks in Hanoi, Vietnam: New evidence on early warning. PLoS Negl Trop Dis. 2020;14(1):1-15. http://doi.org/10.1371/journal.pntd.0007997

41. Panggabean $M$, Siahaan $L$, Panggabean $Y C$. Relationship of presence larvaes aedes aegypti in the water containers with dengue hemorrhagic fever in the Sei Kera Hilir 1 village sub-district Medan Perjuangan Medan city. J Phys Conf Ser. 2019;1317(1):3-8. http://doi. org/10.1088/1742-6596/1317/1/012104

42. Kusnoputranto $\mathrm{H}$, Sintorini MM, Utomo SW, Aliyyah $\mathrm{N}$, Sinaga ER, Pratiwi OA. Transmission of dengue hemorrhagic fever and climate variability in Jakarta. IOP Conf Ser Earth Environ Sci. 2019;314:012071. http://doi. org/10.1088/1755-1315/314/1/012071

43. Husnina Z, Clements AC, Wangdi K. Forest cover and climate as potential drivers for dengue fever in Sumatra and Kalimantan 2006-2016: A spatiotemporal analysis. Trop Med Int Health. 2019;24(7):888-98. http://doi.org/10.1111/tmi.13248 PMid:31081162

44. Astuti EP, Dhewantara PW, Prasetyowati H, Ipa M, Herawati C, Hendrayana K. Paediatric dengue infection in Cirebon, Indonesia: A temporal and spatial analysis of notified dengue incidence to inform surveillance. Parasit Vectors. 2019;186:1-12. http://doi.org/10.1186/s13071-019-3446-3

45. Seah A, Aik J, Ng LC, Tam CC. The effects of maximum ambient temperature and heatwaves on dengue infections in the tropical city-state of Singapore a time series analysis. Sci Total Environ. 2021;775:145117. http://doi.org/10.1016/j. scitotenv.2021.145117 PMid:33618312

46. Pol SS, Rajderkar SS, Dhabekar PD, Gokhe SS. Effect of climatic factors like rainfall, humidity and temperature on the 
dengue cases in the metropolitan city of Maharashtra. Int J Community Med Public Health. 2021;8(2):672. http://doi. org/10.18203/2394-6040.ijcmph20210220

47. Zhang Y, Riera J, Ostrow K, Siddiqui S, de Silva H, Sarkar S et al. Modeling the relative role of human mobility, land-use and climate factors on dengue outbreak emergence in Sri Lanka. 2020;20:649.

48. Nguyen LT, Le HX, Nguyen DT, Ho HQ, Chuang TW. Impact of climate variability and abundance of mosquitoes on dengue transmission in central Vietnam. Int J Environ Res Public Health. 2020;17(7):2453. http://doi.org/10.3390/ijerph17072453 PMid:32260252

49. Tran BL, Tseng WC, Chen CC, Liao SY. Estimating the threshold effects of climate on dengue: A case study of Taiwan. Int J Environ Res Public Health. 2020;17(4):1-17. http://doi. org/10.3390/ijerph17041392 PMid:32098179

50. Salim MF, Syairaji M. Time-series Analysis of Climate Change Effect on Increasing of Dengue Hemorrhagic Fever (DHF) Case with Geographic Information System Approach in Yogyakarta, Indonesia. Vol. 2. In: International Proceedings the $2^{\text {nd }}$ International Scientific Meeting on Health Information Management 2020; 2020. p. 248-56.

51. Adnan RA, Ramli MF, Othman HF, Asha'ri ZH. Implication of climatic factors on dengue fever in urban area: Case study in 2012-2016. EnvironmentAsia. 2020;13(3):89-102. http://doi. org/10.14456/ea.2020.45

52. Haryanto B. Dengue hemorrhagic fever vulnerability to climate in Indonesia: Assessment, projection and mapping. In: International Conference on Innovative Trends in Multidiscplinary Academic Research (ITMAR); 2014. p. 20-1. http://doi.org/10.1289/ isee.2014.p2-342

53. Kasman K, Ishak NI, Hastutiek P, Suprihati E, Mallongi A. Identification of active compounds of ethanol extract of citrus amblycarpa leaves by analysis of thin-layer chromatography and gas chromatography-mass spectrometry as bioinsecticide candidates for mosquitoes. Open Access Maced J Med Sci. 2020;8(T2):1-6. http://doi.org/10.3889/ OAMJMS.2020.5207

54. Fuadiyah EA, Widawati M. Climate factors are affecting dengue hemorrhagic fever (DHF) case in Cimahi of 2004-2013. Spirakel. 2018;10(2):86-96.

55. Selvarajoo S, Liew JW, Tan W, Lim XY, Refai WF, Zaki RA Sethi $\mathrm{N}$, et al. Knowledge, attitude and practice on dengue prevention and dengue seroprevalence in a dengue hotspot in Malaysia: A cross-sectional study. Sci Rep. 2020;10(1):1-13. http://doi.org/10.1038/s41598-020-66212-5

56. Sari TW, Putri R. Mosquito breeding place eradication and dengue hemorrhagic fever event in Payung Sekaki health center Pekanbaru city, a case control study. J Epidemiol Kesehat Indones. 2020;3(2):55-60. http://doi.org/10.7454/epidkes. v3i2.1781 